\title{
PENURUNAN KADAR LIGNIN OLEH KAPANG PELAPUK KAYU INDIGENOUS Thermothelomyces guttulata KLUM2 SEBAGAI METODE ALTERNATIF UNTUK MENCIPTAKAN KANDIDAT PAKAN TERNAK YANG MUDAH DICERNA
}

\author{
Sindy Oktari Putri ${ }^{1}$, Evi Susanti ${ }^{1,2^{*}}$ \\ ${ }^{1}$ Jurusan Kimia, Fakultas Matematika dan Ilmu Pengetahuan Alam, Universitas Negeri Malang \\ ${ }^{2}$ Prodi Bioteknologi, Fakultas Matematika dan Ilmu Pengetahuan Alam, Universitas Negeri Malang \\ *e-mail: evi.susanti.fmipa@um.ac.id
}

Received 22 November 2021

Accepted 9 Desember 2021

\begin{abstract}
Abstrak
Limbah Taman Kampus berupa rumput pahitan berpotensi sebagai pakan ternak ruminansia karena kandungan selulosanya yang tinggi, namun selulosa tersebut masih dalam bentuk lignoselulosa yang menurunkan ketercernaannya pada rumen ruminansia sehingga bentuk lignoselulosa tersebut perlu didegradasi untuk menurunkan kadar lignin sebagai zat anti nutrisi. Fermentasi limbah rumput pahitan menggunakan Kapang Pelapuk Kayu Indigenous Thermothelomyces guttulata $\mathrm{KLUM}_{2}$ merupakan metode alternatif untuk menurunkan kadar lignin dalam menciptakan kadidat pakan ternak yang mudah dicerna dari limbah rumput pahitan. Tujuan penelitian ini adalah mengamati pengaruh jumlah spora dan waktu fermentasi terhadap kandungan lignin, lemak kasar, dan protein kasar selama fermentasi rumput pahitan oleh kapang pelapuk kayu Thermothelomyces guttulata $\mathrm{KLUM}_{2}$. Penelitian ini merupakan penelitian eksperimen laboratories menggunakan metode RAL dengan variasi jumlah spora $\left(1,23 \times 10^{7} ; 3,07 \times 10^{7} ;\right.$ dan $\left.6,14 \times 10^{7} \mathrm{sel}\right)$ dan waktu fermentasi $(14$ dan 21 hari). Tahapan penelitian ini: (1) Preparasi limbah rumput, (2) Preparasi suspensi spora Thermothelomyces guttulata $\mathrm{KLUM}_{2}$, (3) Fermentasi limbah rumput pahitan oleh Thermothelomyces guttulata $\mathrm{KLUM}_{2}$, dan (4) Analisis kadar lignin, protein kasar, dan lemak kasar. Hasil penelitian yang dilakukan menunjukkan bahwa fermentasi limbah rumput pahitan dengan Thermothelomyces guttulata $\mathrm{KLUM}_{2}$ mampu menurunkan kadar lignin dan meningkatkan kadar lemak serta protein kasar, namun secara umum tidak dipengaruhi oleh variasi lama dan jumlah spora. Kondisi optimum yang diperoleh adalah kombinasi jumlah spora $6,14 \times 10^{7}$ sel dan waktu fermentasi 21 hari menghasilkan kadar lignin, kadar lemak kasar dan kadar protein kasar berturut-turut sebesar 12,20 $\pm 0,25 \%$; $2,51 \pm 0,38 \%$; dan $11,17 \pm 0,08 \%$. Berdasarkan hal tersebut maka fermentasi menggunakan KPK Indigenous Thermothelomyces guttulata $\mathrm{KLUM}_{2}$ berpotensi dalam rangka menciptakan pakan ternak yang mudah dicerna oleh ruminansia.
\end{abstract}

Kata kunci: Kapang Pelapuk Kayu, KLUM2, rumput pahitan, fermentasi, lignin

\begin{abstract}
Campus Park waste like pahitan grass has a potential as ruminant animal feed because of its high cellulose content, but the cellulose is still in the form of lignocellulose which reduces its digestibility in the rumen of ruminants so that the lignocellulosic needs to be degraded to reduce levels of lignin as an anti-nutrient substance. Pahitan grass waste fermentation using Indigenous Wood-rot Fungi Thermothelomyces guttulata $\mathrm{KLUM}_{2}$ is an alternative method to reduce lignin content to create digestable animal feed candidates from pahitan grass waste. The purpose of this study was to observe the effect of the number of spores and
\end{abstract}


fermentation time on the content of lignin, crude fat, and crude protein during the fermentation of bitter grass by the wood rot fungi Thermothelomyces guttulata $\mathrm{KLUM}_{2}$. This study is a laboratory experimental study using the CRD method with variations in the number of spores $\left(1.23 \times 10^{7} ; 3.07 \times 10^{7}\right.$; and $6.14 \times 10^{7}$ cells $)$ and fermentation time (14 and 21 days). The stages of this research: (1) Preparation of grass waste, (2) Preparation of spore suspension of Thermothelomyces guttulata $\mathrm{KLUM}_{2}$, (3) Fermentation of pahitan grass waste by Thermothelomyces guttulata $\mathrm{KLUM}_{2}$, and (4) Analysis of lignin content, crude protein, and crude fat. The results of the research showed that the fermentation of pahitan grass waste with Thermothelomyces guttulata $\mathrm{KLUM}_{2}$ was generally able to reduce lignin levels and increase fat and crude protein levels, but was not affected by variations in duration and number of spores. The optimum conditions obtained were the combination of the number of spores $6.14 \times 10^{7}$ cells and a fermentation time of 21 days resulted in lignin content, crude fat content and crude protein content of $12.20 \pm 0.25 \% ; 2.51 \pm 0.38 \%$; and $11.17 \pm 0.08 \%$. Based on this, fermentation using KPK Indigenous Thermothelomyces guttulata $\mathrm{KLUM}_{2}$ has the potential to be used as an alternative method in creating ruminant feed that has high digestibility.

Keywords: Wood Rot Fungi, KLUM2, pahitan grass, fermentation, lignin

\section{Pendahuluan}

Keterbatasan pakan hijauan untuk ternak ruminansia menjadi masalah klasik bagi para peternak konvensional di Indonesia. Pengadaan pakan hijauan semakin lama semakin terbatas akibat berkurangnya jumlah lahan sumber pakan hijauan terutama di daerah perkotaan, diperparah dengan perubahan musim yang semakin tidak menentu dan masih terbatasnya teknologi pengawetan pakan.

Taman Kampus Universitas Negeri Malang merupakan lahan terbuka hijau di area kampus yang berfungsi untuk menambah nilai estetika kampus, tempat penghasil oksigen dan penyerap $\mathrm{CO}_{2}$, daerah resapan air, dan juga berperan sebagai pembatas bangunaan. Berdasarkan hasil wawancara dengan Pengelola Taman di Universitas Negeri Malang diketahui bahwa Pemeliharaan rutin pada Taman Kampus di Fakultas Sastra, Universitas Negeri Malang menghasilkan limbah rata-rata sebanyak 1 bak kontainer dengan volume 6.000 Liter setiap minggunya. Limbah Taman Kampus terbanyak berasal dari golongan rumput-rumputan, terutama rumput pahitan (Axonopus compressus).

Rumput pahitan memiliki kadar selulosa $42.5 \%$ dan hemiselulosa $27,1 \%$
(Lee, 2020) sehingga membuka peluang sebagai bahan baku pakan hijauan ruminansia. Sayangnya potensi tersebut terhalang untuk dimanfaatkan karena adalanya zat anti nutrisi berupa lignin. Lignin pada hijauan dapat menghambat ketercernaan suatu pakan pada ternak karena lignin tahan terhadap hidrolisis enzimatik oleh mikroba rumen (Hattaka, 2000). Lignin dalam hijauan juga membentuk ikatan lignoselulosa yang kuat dan erat sehingga dapat menghambat ketercernaan selulosa dan hemiselulosa oleh enzim selulase dan hemiselulase dalam rumen (Handayani et al., 2018; Wibowo et al., 2019). Akibatnya, ketercernaan pakan ternak terbatas dan nutrisi yang diserap tidak maksimal. Selain itu, pemberian pakan pada ternak harus memperhatikan kualitas maupun kuantitas pakan ternak seperti kadar protein, lemak dan vitamin harus dapat tercukupi dan memenuhi standar (Haryanti, 2009). Berdasarkan SNI 31481-2017 dan SNI 3148-2-2017 tentang persyaratan mutu pakan ternak ruminansia, kadar lemak kasar yang dapat diterima oleh ternak maksimal 6-12\%, kadar protein kasar minimal 12-21\%, dan kadar abu maksimal 8-12\%. 
Kapang pelapuk kayu (KPK) merupakan salah satu mikroorganisme kelompok fungi yang mampu mendegradasi lignin pada kayu karena kemampuannya menghasilkan ligninase (Alesia et al., 2020). Ligninase terdiri dari lignin peroksidase (LiP), mangan peroksidase $(\mathrm{MnP})$ dan fenol oskidase (lakase) (Hikam, 2021). Beberapa kajian menunjukkan apabila KPK dari spesies Phanerochaete chrysosporium selain efektif menghasilkan ligninase untuk mendegradasi lignin juga dapat meningkatkan nilai gizi suatu limbah untuk pakan ternak. Menurut Mulyo et al., (2014) fermentasi oleh $P$. chrysosporium dapat menurunkan kadar lignin dan meningkatkan kadar protein kasar kulit buah kakao. Sejalan dengan penelitian tersebut, Imsya et al. (2014) menunjukkan bahwa fermentasi pelepah kelapa sawit oleh $P$. chrysosporium dapat menurunkan kadar serat kasar, meningkatkan kadar protein kasar, lemak kasar dan abu.

$\mathrm{KLUM}_{2}$ merupakan salah satu koleksi isolat KPK indigenous di Laboratorium Biokimia UM yang telah berhasil diisolasi dari perkebunan kakao Sepawon, Kediri (Delila et al., 2017). Isolat $\mathrm{KLUM}_{2}$ berhasil diidentifikasi sebagai Thermothelomices guttulata yang termasuk ke dalam filum Ascomycetes (Iqbal, 2018), yang mana kelompok filum tersebut diketahui memiliki kemampuan dalam mendegradasi lignin dengan melibatkan enzim peroksidase dan lakase (Sánchez-Corzo et al., 2021). Isolat $\mathrm{KLUM}_{2}$ berpotensi sebagai sumber enzim ligninolitik karena dapat mereduksi pewarna metilen biru dalam media selektif (Delila et al., 2017), menghasilkan LiP, MnP, dan Lakase pada medium Kirk baik dengan sumber karbon glukosa (Arinta, 2018), maupun serbuk gergajian kayu dan alkali lignin (Nurlailiyah, 2020). Dengan demikian KPK Thermothelomyces guttulata $\mathrm{KLUM}_{2}$ berpotensi digunakan sebagai metode alternatif dalam menciptakan pakan ternak ruminansia yang memiliki ketercernaan tinggi karena kemampuannya dalam mendegradasi lignin.

Berdasarkan fakta-fakta yang dipaparkan, Peneliti tertarik untuk mempelajari pengaruh jumlah sel dengan lama fermentasi untuk menurunkan kadar lignin sebagai zat anti nutrisi dan pengaruhnya terhadap perubahan kadar lemak kasar dan kadar protein kasar limbah rumput pahitan selama proses fermentasi oleh kapang pelapuk kayu sehingga diharapkan dapat menghasilkan limbah yang berpotensi sebagai pakan ternak ruminansia yang mudah untuk dicerna dan memenuhi SNI pakan ternak.

\section{Metode Penelitian \\ Alat dan Bahan}

Alat yang digunakan pada penelitian ini antara lain berupa peralatan gelas dan peralatan non gelas. Peralatan non gelas yang digunakan adalah: timbangan (neraca), plastic wrap, benang, sarung tangan lateks, sumbat kapas, siring (berisi kapas steril), plastik, label, jarum enten, bola hisap, baskom, kertas saring, indikator universal, kertas aluminium, mikropipet $10 \mathrm{~mL}$, Biolo Mix grinder swing 2000 gram tegangan 3000 watt voltase 220 Volt, ayakan 9 Mesh, autoclave, hot plate magnetic stirrer Thermo Fisher Scientific SP88857105 luas pemanas $10,8 \times 10,8 \mathrm{~cm}$ voltase 120 Volt, hot plate magnetic stirrer Thermo Scientific Cimarec SP131015Q luas pemanas $18,4 \times 18,4 \mathrm{~cm}$ voltase 230 Volt, oven, inkubator, almari asam, almari es, vortex, Loyang aluminium, statif dan klem, aerator pump Yamaho WP-103 tegangan 25 watt aliran 1300 L/jam, selang diameter $8 \mathrm{~mm}$, spektrofotometer UV-Vis, Peralatan gelas yang digunakan adalah: botol kering berukuran $150 \mathrm{~mL}$ dan $1000 \mathrm{~mL}$, pipet tetes, gelas ukur 10 $\mathrm{mL}$ dan $100 \mathrm{~mL}$, spatula, gelas beaker 100 $\mathrm{mL}$, desikator, Erlemneyer $250 \mathrm{~mL}$ dan $500 \mathrm{~mL}$, tabung reaksi $15 \mathrm{~mL}$, set alat Soxhlet $100 \mathrm{~mL}$, labu ukur $100 \mathrm{~mL}$ dan $1000 \mathrm{~mL}$, corong kaca $75 \mathrm{~mm}$. 
Bahan-bahan yang digunakan dalam penelitian ini terbagi atas dua jenis, yaitu bahan berderajat p.a dan bahan berderajat teknis. Bahan berderajat p.a yaitu Potato Dextrose Agar (PDA) (Oxoid kode CM0139), Petroleum eter (Smart Lab), $\mathrm{H}_{2} \mathrm{SO}_{4} \quad 98 \%$ (Smart Lab), Tween 80 (Smart Lab), Asam asetat (Smart Lab), dan Natrium asetat (Smart Lab). Bahan berderajat teknis, yaitu isolat kapang pelapuk kayu Thermothelomyces guttulata $\mathrm{KLUM}_{2}$, limbah rumput pahitan yang berasal dari dari taman Fakultas Sastra Universitas Negeri Malang, akuades, lysorin, detergen, spirtus, dan alkohol $70 \%$.

\section{Preparasi Limbah Taman}

Bahan baku yang digunakan dalam percobaan yaitu limbah rumput pahitan. Limbah rumput yang akan digunakan untuk penelitian, sebelumnya dilakukan preparasi. Proses preparasi diawali dengan dicuci secara bersih limbah rumput pahitan sampai tanah yang menempel hilang. Selanjutnya rumput dikeringkan selama dua hari pada terik matahari selama 5 jam antara pukul 10.0015.00. Limbah rumput pahitan yang sudah dikeringkan di udara, lalu dihaluskan dengan grinder, diayak dengan ukuran 20 mesh, dan sampel yang digunakan ialah yang lolos penyaringan. Berikutnya dilakukan sterilisasi dengan autoklaf selama 25 menit dengan suhu $121{ }^{\circ} \mathrm{C}$ dan tekanan 15 lbs. Sebagian sampel yang telah dipreparasi, dilakukan uji kadar lignin, lemak kasar, protein kasar, dan abu dan sebagian sampel yang lain digunakan untuk tahap berikutnya yaitu proses fermentasi.

\section{Preparasi Suspensi Spora} Thermothelomyces guttulata KLUM 2

Semua tahap preparasi suspensi spora dilakukan secara aseptik. Isolat kapang pelapuk kayu Indigenous Thermothelomyces guttulata $\mathrm{KLUM}_{2}$ diinokulasi pada media PDA miring selama 14 hari. Selanjutnya spora diambil merujuk pada Susanti (2017). Jumlah spora dihitung berdasarkan konversi yang telah ditentukan oleh Oktavia (2018) menyatakan bahwa nilai OD660 suspensi spora $\mathrm{KLUM}_{2}$ yang diperoleh dengan metode tersebut sebesar 4,1 setara dengan densitas standar sebesar $2,6 \times 10^{6} \mathrm{sel} / \mathrm{mL}$.

\section{Proses Fermentasi}

Proses fermentasi merujuk Imsya, et al. (2014) dengan modifikasi. Variasi jumlah spora Thermothelomyces guttulata $\mathrm{KLUM}_{2}$ yang digunakan yaitu $1,23 \times 10^{7}$; $3,07 \times 10^{7}$; dan $6,14 \times 10^{7}$ sel Masingmasing diinokulasikan ke dalam media fermentasi yang terdiri dari 5 gram gilingan rumput pahitan ditambah dengan larutan buffer asetat dengan volume akhir $50 \mathrm{~mL}$. Setiap variasi jumlah spora difermentasi selama 14 dan 21 hari. Hasil fermentasi ditentukan kadar lignin, lemak kasar, dan kadar protein kasarnya.

\section{Penentuan Kadar Lignin}

Kadar lignin ditentukan dengan metode Klason dan dilakukan sebanyak dua kali ulangan. Sebanyak 0,2 gram sampel dimaserasi dengan pelarut etanol selama 12 jam. Sampel hasil estraksi dipindah ke dalam Erlenmyer dan ditambah 7,5 mL Asam sulfat $72 \%$ dan dimasukkan bak perendaman pada temperatur $20{ }^{\circ} \mathrm{C}$ sambil diaduk dengan batang pengaduk selama 2-3 menit. Erlenmeyer ditutup dan dibiarkan pada bak perendaman selama dua jam sambil sesekali diaduk. Sampel dituang ke dalam Erlenmeyer dan diencerkan dengan aquadest hingga konsentrasi Asam sulfat menjadi 3\% lalu dilakukan autoklaf selama 30 menit dengan suhu $121{ }^{\circ} \mathrm{C}$. Didinginkan dan didiamkan selama 2 jam sampai endapan lignin mengendap sempurna. Disaring endapan dengan kertas saring yang telah diketahui beratnya. Dicuci endapan lignin dengan air panas hingga netral. Dicuci endapan lignin dengan air panas hingga netral. Endapan yang diperoleh dioven pada suhu $105{ }^{\circ} \mathrm{C}$ selama 30 menit lalu didinginkan 
dalam desikator dan dtimbang hingga didapat berat konstan. Kadar lignin ditentukan menggunakan persamaan 1 .

$\%$ Lignin $=\frac{\text { berat endapan lignin }}{\text { berat sampel }} \times 100 \%$

\section{Penentuan Kadar Lemak Kasar}

Kadar lemak kasar ditentukan dengan metode Soxhletasi dan dilakukan sebanyak dua kali ulangan. Ekstraksi lemak kasar pada sampel dilakukan dengan Soxhlet menggunkan pelarut lemak yaitu petroleum eter. Langkah awal adalah sampel ditimbang sebanyak 2 gram setiap pengujian dimasukkan ke dalam kertas saring lalu dibungkus rapat dan dipasang tali. Berikutnya labu lemak dan pecahan porselen juga dilakukan penimbangan. Sampel disambungkan pada tabung Soxhlet, ditambah $\pm 150 \mathrm{~mL}$ petroleum eter, Dirangkai alat, dan dilakukan ekstraksi selama \pm 4 jam. Labu lemak yang berisi sampel dioven dengan suhu $105{ }^{0} \mathrm{C}$ selama 2 jam, selanjutnya dimasukan desikator \pm 30 menit. Labu lemak ditimbang hingga diperoleh bobot tetap. Rumus perhitungan kadar lemak kasar dapat dilihat pada persamaan 2 .

$\%$ Lemak kasar $=\frac{\text { berat lemak }}{\text { berat sampel }} \times 100 \%$

\section{Penentuan Kadar Protein Kasar}

Pengujian kadar protein kasar dilakukan menggunakan metode Kjeldahl dengan jumlah sampel sebanyak 1 gram setiap kali ulangan. Proses ini dilakukan di Laboratorium Pakan Ternak Dinas Peternakan dan Perikanan Kabupaten Blitar yang berlokasi di Jalan Cokroaminoto No. 22, Kota Blitar.

\section{Hasil dan Pembahasan}

\section{Karakteristik Kimiawi Limbah Rumput Pahitan}

Rumput pahitan segar yang merupakan limbah hasil pemangkasan taman kampus tampak berwarna hijau terang. Setelah dikeringkan, rumput tampak layu dan berwarna coklat. Hasil preparasi akhir berupa serbuk rumput kering yang lolos melalui ayakan 20 Mesh. (Gambar 1).

Rumput pahitan mengandung kadar lignin yang tinggi sebesar $19,05 \pm 0,38 \%$, kadar protein kasarnya sebesar $10,79 \pm 0,19 \%$ dan kadar 1,12 $\pm 0,15$ (Tabel 1). Hasil ini menunjukkan bahwa rumput pahitan kurang baik jika digunakan secara langsung sebagai pakan hijauan ternak, selain kadar ligninnya tinggi, kadar protein lebih rendah daripada yang ditetapkan dalam SNI.

\section{Peremajaan Isolat KPK Indigenous Thermothelomyces guttulata KLUM}

Hasil pengamatan menunjukkan jika Thermothelomyces guttulata $\mathrm{KLUM}_{2}$ yang diinkubasi selama 14 hari pada media PDA miring, menghasilkan miselium berwarna coklat dan kasar seperti kapas di bagian permukaannya (Gambar 2). Morfologi yang dihasilkan memiliki kemiripan dengan penelitian sebelumnya, di mana hal tersebut menunjukkan jika isolat yang dibiakkan dan digunakan merupakan biakan murni seperti biakan induknya.

Tabel 1. Kandungan rumput pahitan (\%) sebelum fermentasi

\begin{tabular}{lcc}
\hline Komponen & $\begin{array}{c}\text { Kadar } \\
(\boldsymbol{\%})\end{array}$ & $\begin{array}{c}\text { SNI } \\
\text { Pakan } \\
\text { Ruminansia } \\
(\boldsymbol{\%})\end{array}$ \\
\hline Lignin & 19,05 & - \\
& $\pm 0,38$ & - \\
Protein & 10,79 & Minimal \\
kasar & $\pm 0,19$ & $12-21$ \\
Lemak & 1,12 & Maksimal \\
kasar & $\pm 0,15$ & $6-12$ \\
\hline
\end{tabular}



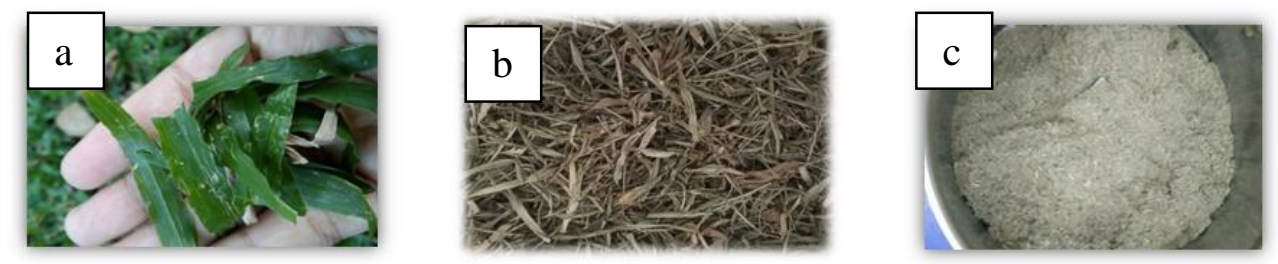

Gambar 1. Tahapan preparasi sampel limbah rumput pahitan: (a) sebelum preparasi; (b) setelah pengeringann; (c) setelah penggilingan
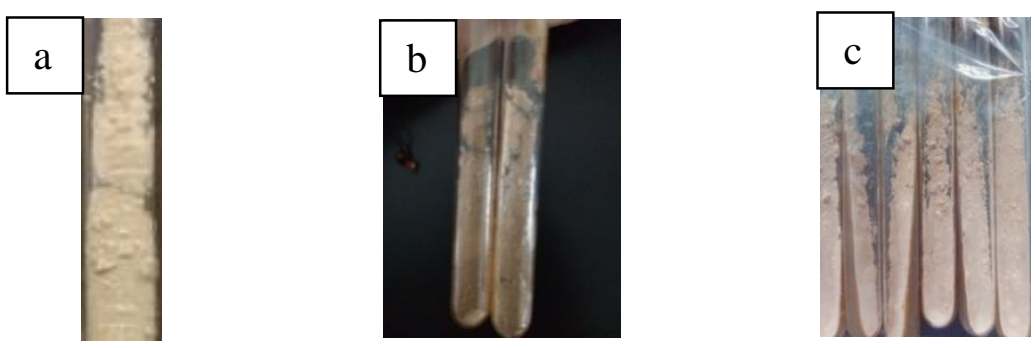

Gambar 2. Morfologi secara makroskopis Thermothelomyces guttulata $\mathrm{KLUM}_{2}$ pada media PDA miring selama 14 Hari (a) Nurlailiyah (2020); (b) Mutmainah (2020); (c) Peneliti.

Kapang Pelapuk Kayu Thermothelomyces guttulata KLUM2

Kadar Lignin

Hasil penelitian menunjukan terjadinya penurunan kadar lignin dalam limbah rumput pahitan oleh KPK Thermothelomyces guttulata $\mathrm{KLUM}_{2}$. Perlakuan variasi jumlah spora (dengan waktu yang tetap) yang dipilih tidak menunjukkan terjadinya penurunan kadar lignin, sedangkan perlakuan variasi waktu fermentasi (dengan jumlah spora yang tetap) menunjukkan terjadinya penurunan kadar lignin. Semakin lama waktu fermentasi, semakin besar penurunan kadar lignin yang terjadi (Tabel 2).

Tabel 2. Kadar lignin (\%) pada fermentasi limbah rumput pahitan menggunakan

Thermothelomyces guttulata $\mathrm{KLUM}_{2}$

\begin{tabular}{ccc}
\hline Jumlah & \multicolumn{2}{c}{ Lama Fermentasi } \\
\cline { 2 - 3 } Spora (Sel) & 14 Hari & 21 Hari \\
\hline 0 & $18.75 \pm 0.00$ & $18.82 \pm 0,25$ \\
$1,23 \times 10^{7}$ & $16,74 \pm 0,10$ & $14,91 \pm 0,08$ \\
$3,07 \times 10^{7}$ & $17,02 \pm 0,40$ & $14,52 \pm 0,56$ \\
$6,14 \times 10^{7}$ & $17,62 \pm 0,78$ & $12,20 \pm 0,25$ \\
\hline
\end{tabular}

Penurunan kadar lignin yang terjadi disebabkan oleh adanya perombakan kandungan lignin oleh aktivitas enzim lignoselulase yang dihasilkan oleh kapang pelapuk kayu (Noeferdiman \& Yani, 2013; Suningsih et al, 2019). Semakin lama waktu fermentasi maka semakin banyak jumlah enzim yang dihasilkan sehingga penurunan kadar lignin akan semakin besar.

Parameter ketercernaan pakan ternak pada penelitian ini diamati dari hasil perubahan kadar lignin yang terjadi selama proses fermentasi. Merujuk penelitian sejenis, Imsya et al. (2014) melakukan fermentasi limbah pelepah sawit oleh $P$. chrysosporium, menggunakan kadar serat kasar sebagai parameter ketercernaan pakan ternak. Hal ini menyebabkan penelitian ini tidak dapat dibandingkan secara langsung dengan penelitian tersebut. Pada penelitian Imsya et al. (2014) kadar serat kasar mengalami penurunan tertinggi dari $39,85 \%$ menjadi $25,51 \%$.

Serat kasar sendiri terdiri dari lignin, selulosa, dan hemiselulosa yang saling berikatan erat. Pada ternak ruminansia, selulosa dan hemiselulosa dapat dicerna 
dengan baik di dalam rumen oleh bantuan mikroba penghasil enzim selulase dan hemiselulase. Selulosa dan hemiselulosa didegradasi untuk menghasilkan energi yang digunakan untuk pertumbuhan mikroba rumen maupun induk semang (Wandra et al., 2020). Sementara lignin yang berikatan kuat dengan selulosa dan hemiselulosa justru berperan dalam menghambat ketercernaan suatu pakan ternak (Handayani et al., 2018; Wibowo et al., 2019). Keberhasilan penelitian ini dilihat dari adanya penurunan kadar lignin yang artinya mampu meningkatkan ketercernaan suatu pakan ternak. Data penelitian menunjukkan penurunan kadar lignin tertinggi diperoleh pada kombinasi jumlah spora $6,14 \times 10^{7}$ sel dan waktu fermentasi 21 hari, yaitu turun dari $19,05 \pm 0,38 \%$ menjadi $12,20 \pm 0,25 \%$.

\section{Kadar Lemak Kasar}

Hasil penelitian menunjukan kadar lemak kasar limbah rumput pahitan selama fermentasi dapat dikatakan mengalami peningkatan meski hasil datanya fluktuatif (Tabel 3).

Tabel 3. Kadar lemak kasar (\%) pada fermentasi limbah rumput pahitan menggunakan

Thermothelomyces guttulata $\mathrm{KLUM}_{2}$

\begin{tabular}{clr}
\hline Jumlah & \multicolumn{2}{c}{ Lama Fermentasi } \\
\cline { 2 - 3 } Spora (Sel) & \multicolumn{1}{c}{ 14 Hari } & 21 Hari \\
\hline 0 & $1,395 \pm 0,29$ & $1,45 \pm 0,31$ \\
$1,23 \times 10^{7}$ & $2,49 \pm 0,28$ & $5,47 \pm 1,67$ \\
$3,07 \times 10^{7}$ & $3,435 \pm 0,21$ & $6,32 \pm 1,72$ \\
$6,14 \times 10^{7}$ & $2,435 \pm 0,19$ & $2,51 \pm 0,38$ \\
\hline
\end{tabular}

Perlakuan penambahan jumlah spora (pada waktu fermentasi yang sama) menunjukkan adanya tren di mana kadar lemak kasar naik seiring penambahan jumlah spora $1,23 \times 10^{7}$ sel dan $6,14 \times 10^{7}$ sel tetapi mengalami penurunan setelah penambahan jumlah spora sebesar $6,14 \times 10^{7}$ sel. Menurut Yasar et al. (2019) penurunan kadar lemak kasar diduga disebabkan oleh penggunaan lemak untuk pertumbuhan fungi itu sendiri. Sejalan dengan pernyataan Pratiwi (2015) penurunan kadar lemak dimungkinkan karena aktivitas mikroba dalam memecah lemak menjadi asam lemak dan gliserol sebagai sumber energi. Semakin banyak jumlah sel, semakin banyak pula lemak yang dibutuhkan oleh kapang untuk menghasilkan energi, akibatnya produksi lemak kasar menurun.

Kadar lemak kasar mengalami peningkatan seiring dengan meningkatnya waktu fermentasi. Kenaikan kadar lemak kasar diduga dipengaruhi oleh kenaikan jumlah sel kapang, dan produk metabolitnya berupa lemak seperti komponen membran organel sel kapang itu sendiri tersusun.

Pada penelitian ini juga dilakukan identifikasi apakah ada perubahan kadar lemak kasar, dan kadar protein kasar selama proses fermentasi berlangsung. Hal tersebut dilakukan untuk mengetahui pada penurunan kadar lignin tertinggi, apakah parameter lain seperti kadar lemak kasar dan kadar protein kasar masih memenuhi kriteria sebagai kandidat pakan ternak yang baik atau tidak berdasarkan Standar Nasional Indonesia.

Menurut standar pakan ternak untuk ruminansia, maksimal lemak kasar yang diizinkan untuk dikonsumsi ternak berkisar 6-12\% tergantung jenis ternaknya. Lemak kasar bagi ternak dimanfaatkan sebagai sumber penghasil energi, namun apabila dikonsumsi secara berlebihan dapat mengganggu proses pencernaan dalam rumen, diantaranya mengakibatkan lemak akan menyelubungi serat pakan sehingga tidak dapat terdegradasi dengan baik, bahkan adanya lemak tidak jenuh yang bersifat toksik dapat mengganggu populasi probiotik di dalam rumen (Wina et al., 2013). Pada kondisi optimum penurunan kadar lignin (kombinasi jumlah spora $6,14 \times 10^{7}$ sel dan waktu fermentasi 21 hari) kadar lemak kasar yang dihasilkan sebesar $2,51 \pm 0,38 \%$. Kadar lignin yang diperoleh masih memenuhi syarat kriteria pakan 
ternak yang layak dikonsumsi oleh ruminansia (6-12\%) berdasarkan SNI 3148-1-2017 dan SNI 3148-2-2017 tentang persyaratan mutu pakan ternak.

\section{Kadar Protein Kasar}

Kadar protein kasar yang dihasilkan dari penelitian menunjukkan terdapat adanya peningkatan meski hasil data yang dihasilkan cenderung fluktuatif, khususnya pada fermentasi hari ke-21, sedangkan fermentasi pada hari ke-14 terjadi peningkatan kadar protein kasar dari $10,82 \pm 0,06 \%$ menjadi $11,455 \pm$ $0,08 \%$. Peningkatan kadar protein pada hari ke-14 diduga karena pertumbuhan sel kapang masih di fase eksponensial, sedangkan penurunan kadar protein kasar pada hari ke-21 kemungkinan karena kapang memasuki fase stationer yang menggunakan sebagian protein yang dihasilkan di fase eksponensial digunakan sebagai sumber energi (Tabel 4).

Tabel 4. Kadar protein kasar (\%) pada fermentasi limbah rumput pahitan menggunakan Thermothelomyces guttulata $\mathrm{KLUM}_{2}$

\begin{tabular}{crc}
\hline Jumlah & \multicolumn{2}{c}{ Lama Fermentasi } \\
\cline { 2 - 3 } Spora (Sel) & 14 Hari & 21 Hari \\
\hline 0 & $10,82 \pm 0,06$ & $10,49 \pm 0,06$ \\
$1,23 \times 10^{7}$ & $11,10 \pm 0,30$ & $10,895 \pm 0,30$ \\
$3,07 \times 10^{7}$ & $11,252 \pm 0,57$ & $9,87 \pm 0,57$ \\
$6,14 \times 10^{7}$ & $11,455 \pm 0,08$ & $11,17 \pm 0,08$ \\
\hline
\end{tabular}

Protein kasar atau $\mathrm{N}$ total dimanfaatkan oleh mikroba pada rumen ruminansia untuk pertumbuhan dan sintesis protein mikroba dalam mencerna nutrien (Zahera et al., 2020). Kekurangan protein akan menurunkan efektivitas pencernaan pakan pada rumen karena pengaruh jumlah protein mikroba yang dihasilkan. Kadar protein kasar yang dihasilkan pada kondisi optimim penurunan kadar lignin yaitu sebesar $11,17 \pm 0,08 \%$. Meskipun kadar protein kasar yang dihasilkan hampir mendekati nilai minimal $12 \%$, namun masih belum sesuai dengan standar pakan ternak berdasarkan SNI 3148-1-2017 dan SNI 3148-2-2017 (12$21 \%$ ). Untuk memenuhi syarat minimal kadar protein kasar yang diberikan pada ruminansia dapat dilakukan dengan penambahan konsentrat pada pakan ternak.

\section{Kesimpulan}

Hasil penelitian yang dilakukan menunjukkan bahwa fermentasi limbah rumput pahitan mampu menurunkan kadar lignin dan meningkatkan kadar lemak kasar dan protein kasar namun secara umum tidak dipengaruhi oleh variasi lama dan jumlah spora. Kondisi optimum yang diperoleh adalah kombinasi jumlah spora $6,14 \times 10^{7}$ sel dan waktu fermentasi 21 hari menghasilkan kadar lignin, kadar lemak kasar dan kadar protein kasar berturut-turut sebesar $12,20 \pm 0,25 \%$; $2,535 \pm 0,35 \%$; dan $11,17 \pm 0,08 \%$. Berdasarkan hal tersebut maka fermentasi menggunakan KPK Indigenous Thermothelomyces guttulata $\mathrm{KLUM}_{2}$ berpotensi digunakan sebagai metode alternatif dalam menciptakan pakan ternak yang mudah dicerna oleh ruminansia.

\section{Ucapan Terimakasih}

Ucapan terimakasih atas pendanaan penelitian melalui Hibah Skripsi PNBP UM 2021 dengan nomor surat tugas 5.3.1420/UN32.14/LT/2021 oleh lembaga Penelitian dan Pengabdian Masyarakat (LP2M) Universitas Negeri Malang. 


\section{Daftar Pustaka}

Alesia, M., Suwandi, S., Suparman, S. 2021. Aktivitas Pelapukan Kayu Inokulum Ganodermaboninense pada Tumpangsari Bibit Kelapa Sawit dan Talas-Talasan. Sainmatika: Jurnal Ilmiah Matematika dan Ilmu Pengetahuan Alam, 18 (1), 108-115.

Arinta, A. 2018. Penentuan Profil Ligninase dari Kapang Pelapuk Kayu Isolat Indigenus $\mathrm{KLUM}_{1}, \mathrm{KLUM}_{2}$, dan PnUM. Skripsi. Malang: Universitas Negeri Malang.

Delila, L., Susanti, E., Sanjaya, E.H. 2017. Isolation and Screening of Indigenous Fungus Producing Lignin Peroxidase from the Cocoa Plantation in Sepawon Kediri Regency Indonesia. KnE Life Sciences, 3(5), 131-138.

Handayani, S., Harahap, A.E., Saleh, E., 2018. Kandungan fraksi serat silase kulit pisang Kepok (Musa paradisiaca) dengan Penambahan level dedak dan lama Pemeraman yang berbeda. J. Peternakan, 15(1): $1-8$.

Hatakka, A. 2000. Biodegration of Lignin. University of Helsinki, Viikki Biocenter, Department of Applied Chemistry dan Microbiology, Helsinki.

Hikam, A., Yulianti, D., Ginanjar, R. 2021. Diversitas dan Potensi Jamur Lignolitik Asal Seresah Daun. AlHayat: Journal of Biology and Applied Biology, 4(1), 33-42.

Imsya, A., Laconi, E.B., Wiryawan, K.G., Widyastuti, Y. 2014. Biodegradasi Lignoselulosa dengan Phanerochaete chrysosporium terhadap Perubahan Nilai Gizi Pelepah Sawit. Jurnal Peternakan Sriwijaya, 3(2).

Iqbal, M.I. 2018. Analisis Kekerabatan Kapang Pelapuk Kayu Isolat Lokal $\mathrm{KLUM}_{1}$, KLUM 2 dan PnUM Menggunakan Amplikonr RNA dengan Primer Internal Transcribed Spacer Its4 - Its5. Skripsi. Malang: Universitas Negeri Malang.
Lee, J.T.E., Wang, Q., Lim, Y.E., Liu, Z., He, J., Tong, Y.W. 2020. Optimization of Bioaugmentation of The Anaerobic Digestion of Axonopus compressus Cow Grass for The Production of Biomethane. Journal of Cleaner Production, 258.

Mulyo, A.M.H., Yakin, E.A. 2014. Lignin Content in Fermentation of Cocoa Pod Husk (Theobroma Cocoa) Used Phanerochaete Chrysosporium. International Congresson Challenges of Biotechnological Research in Food and Health. Surakarta: Slamet Riyadi University.

Mutmainah, S. 2020. Eksplorasi Ligninase Dari Kapang Pelapuk Kayu Indigenos Thermothelomyces guttulata $\mathrm{KLUM}_{2}$ dalam Medium Kirk-Alkali Lignin. Skripsi. Malang: Universitas Negeri Malang.

Noferdiman, Yani, A. 2013. Kandungan Nutrisi Lumpur Sawit Hasil Fermentasi dengan P. chrysosporium. Agripet, 13(2). 47-52.

Nurlailiyah, E.P. 2020. Pengaruh Variasi Sumber Karbon Terhadap Produksi Ligninase dari Isolat Kapang Pelapuk Kayu Indigenous KLUM $1, \mathrm{KLUM}_{2}$, dan PnUM. Skripsi. Malang: Universitas Negeri Malang.

Pratiwi, I., Fathul, F., Muhtarudin. 2015. The Effect of Different Additioning Starter to Making Silage On Crude Fiber Content, Crude Fat, Water Content, and Material Extract Without Nitrogen Silag. Jurnal Ilmiah Peternakan Terpadu, 3(3): 116-120.

Oktavia, Jonava. 2018. Optimasi Jumlah Sel Inokulum dan Waktu Inkubasi Kapang Pelapuk Kayu Indigenous Isolat $\mathrm{KLUM}_{1}$, dan $\mathrm{KLUM}_{2}$ untuk Dekolorisasi Reactive Black 5. Skripsi. Malang: Universitas Negeri Malang.

Sánchez-Corzo, L.D., Álvarez-Gutiérrez, P.E., Meza-Gordillo, R., VillalobosMaldonado, J.J., Enciso-Pinto, S., Enciso-Sáenz, $\quad$ S. 2021. 
Lignocellulolytic Enzyme Production From Wood Rot Fungi Collected in Chiapas, Mexico, and Their Growth On Lignocellulosic Material. $J$. Fungi, 7, 450.

Suningsih, N., Ibrahim, W., Liandris, O., Yulianti, R. 201). Kualitas Fisik dan Nutrisi Jerami Padi Fermentasi pada Berbagai Penambahan Starter. Jurnal Sain Peternakan Indonesia, 14(2).

Wahyono, T., Jatmiko, E., Firsoni, Hardani, S.N.W., Yunita, E. 201). Evaluasi Nutrien dan Kecernaan In Vitro Beberapa Spesies Rumput Lapangan Tropis di Indonesia. Sains Peternakan, 17(2), 17-23.

Wibowo, S.A., Christiyanto, M., Nuswantoro, L.K., Pangestu, E. 201). Kecernaan Serat Berbagai Jenis Pakan Produk Samping Pertanian (By Product) sebagai Pakan Ternak Ruminansia yang di Uji Secara In Vitro. Jurnal Litbang Provinsi Jawa Tengah, 17(2).

Susanti, E. 2017. Identifikasi Molekular dan Profil Phanerochaete chrysosporium Isolat ITB. Optimasi Produksi, Karakterisasi dan Eksplorasi Potensi Lignin Peroksidasenya untuk Dekolorisasi Reaktif Black 5. Disertasi. Malang: Universitas Brawijaya.
SNI-3148-1-2017. Pakan KonsentratBagian 2: Sapi Perah. Jakarta: Badan Standarisasi Nasional

SNI-3148-2-2017. Pakan KonsentratBagian 2: Sapi Potong. Jakarta: Badan Standarisasi Nasional

Wandra, F.A. Pranowo, A.K., Hernaman, I., Tanuwiria, U.H., Ayuningsih, B. 2020. Fermentabilitas ransum yang mengandung ampas bir dalam cairan rumen (in vitro). Jurnal Sain Peternakan Indonesia, 15 (2), 227 235.

Wina, E., Susana, I.W.R. 2013. Manfaat Lemak Terproteksi untuk Meningkatkan Produksi dan Reproduksi Ternak Ruminansia. WARTAZOA, 23(4), 176-184.

Yasar, S., Tosun, R. 2019. Increasing the nutritional qualities of tomato pomace by yeast fermentation. 4th International conferenceonadvances in natural \& applied sciences agriculture.

Zahera, R., Anggraeni, D., Rahman, Z.A., Evvyernie, D. 2020. Pengaruh Kandungan Protein Ransum yang Berbeda terhadap Kecernaan dan Fermentabilitas Rumen Sapi Perah secara In vitro The Effect of Different Feed Protein Contenton Digestibility and Fermentability of Dairy Rumen using In vitro. Jurnal Ilmu Nutrisi dan Teknologi Pakan, 18(1): 1-6. 